\title{
СТРУКТУРА АССОРТИМЕНТА И КАЧЕСТВО ИКРЫ ЛОСОСЕВОЙ, РЕАЛИЗУЕМОЙ НА ПОТРЕБИТЕЛЬСКОМ РЫНКЕ Г. ЧЕЛЯБИНСКА
}

\author{
Н. Л. Наумова, О. А. Макаева, Е. А. Бурмистров, О. М. Бурмистрова
}

\begin{abstract}
Икра лососевая относится к деликатесным продуктам, обладает неповторимыми органолептическими свойствами и высокой пищевой ценностью, является привлекательным продуктом для подделки, а значит, риск приобрести некачественный товар достаточно высок. Целью исследований стало изучение структуры ассортимента и качества икры лососевой, реализуемой на потребительском рынке е. Челябинска. Материалом послужили: инфрормация, полученная при проведении маркетинговых исследований; образцы икры лососевой зернистой первого сорта "Камчатская рыба», «Путина», «Русская смаковка», образец имитированной лососевой икры «Русское чудо». Установлено, что по количеству наименований на рынке г. Челябинска преобладала имитированная икра, из зернистой - икра горбуши и лосося в металлической таре, массой нетто от 90 до 140 г, рассчитанная на покупателей с разным уровнем достатка, от московских поставщиков. Маркировка всех проб исследуемой икры не соответствовала требованиям нормативной документации: ГОСТ 18173-2004, ТP ТС 022/2011, ТР ЕАЭС 040/2016. По органолептическим и физикохимическим показателям требованиям ГОСТ 18173-2004, предъявляемым к продукции первого сорта, соответствовала икра горбуши «Камчатская рыба». Микробиологическая и токсикологическая безопасность отобранных проб икры лососевой соответствовала нормам TP TC 021/2011, TP ЕАЭС 040/2016, СанПиН 2.3.2.1078-01.
\end{abstract}

Ключевые слова: икра лососевая зернистая, икра имитированная, ассортимент, маркировка, качество, безопасность, производители.

Икра лососевая относится к деликатесным продуктам, производимым предприятиями рыбной промышленности РФ, обладает неповторимыми органолептическими свойствами и высокой пищевой ценностью, является привлекательным продуктом для подделки, а значит, риск приобрести некачественный товар достаточно высок [1-4].

Данные экспертизы показали, что в период 2010-2014 гг. процент несоответствия икры лососевых рыб как по микробиологическим (от 57 до $97 \%$ ), так и по органолептическим (от 58 до $100 \%$ ) показателям увеличивался [5]. Снижение качества икры лососевой зернистой обусловлено нарушением технологии обработки и хранения икры, удаленностью вылова и обработки сырья, недовложением консервантов [6-8].

Заготовки икры в России сокращаются с 2015 года. В январе-апреле 2016 года произведено икры на 29 \% меньше, чем в аналогичном периоде предыдущего года [1]. В числе крупнейших поставщиков икры можно выделить: ГК «Русский икорный дом» из Москвы, ООО Компания «Тунайча» из Сахалинской области, ГК Salmonika и др.

Целью исследований стало изучение структуры ассортимента и качества икры лососевой, реализуемой на потребительском рынке г. Челябинска.

Объектами исследования выступили:

- инфоормация, полученная при проведении маркетинговых исследований торговых предприятий г. Челябинска;

- три образца икры лососевой зернистой первого сорта следующих наименований (рисунок 1):

- «Камчатская рыба», произведенная по ГОСТ 18173-2004 ООО «Камчатская рыба» (Россия, 684005, Камчатская обл., г. Елизово, ул. Школьная, д. 10),

- «Путина», выработанная по ТУ 9264-1904720930-2009 ООО «Путина» (Россия, 197342, г. Санкт-Петербург, ул. Белостровская, д. 28),

- «Русская смаковка», изготовленная по ГОСТ 18173-2004 ОАО «Камчатский комбинат рыбных и пищевых продуктов» (Россия, Камчатский Край, г. Петропавловск-Камчатский, ул. Абеля, д. 6);

- образец имитированной икры лососевой «Русское чудо», произведенной по ТУ 10.20.25-001-4796013-2010 ООО «Европром (Россия, 198095, г. Санкт-Петербург, ул. Маршала Говорова, д. 47). 


\section{СТРУКТУРА АССОРТИМЕНТА И КАЧЕСТВО ИКРЫ ЛОСОСЕВОЙ, РЕАЛИЗУЕМОЙ НА ПОТРЕБИТЕЛЬСКОМ РЫНКЕ Г. ЧЕЛЯБИНСКА}

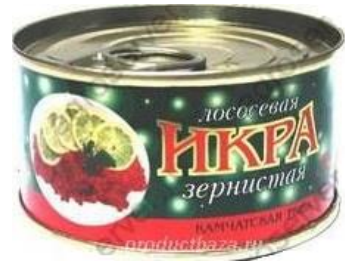

«Камчатская рыба»

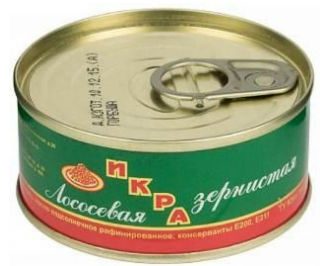

«Путина»

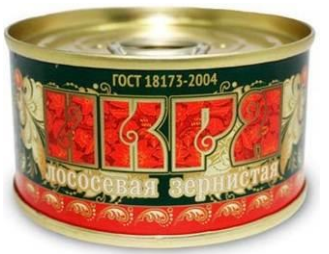

«Русская смаковка»

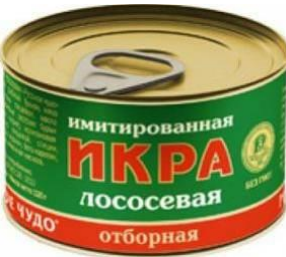

«Русское чудо»

Рисунок 1 - Внешний вид тары отобранных проб икры разных наименований

Маркетинговые исследования по изучению структуры ассортимента икры лососевой проводили методом ритейл-аудита, основанном на анализе степени присутствия и условий продаж товаров-аналогов на 68 торговых предприятиях. Отбор проб икры проводили на «Центральном рынке», в специализированных магазинах: «Красная речка», «Клевый», «Русская рыба», в гипермаркетах: «Светофор», «Spar» и супермаркетах торговых сетей: «Молния», «Магнит», «Дикси» по ГОСТ 313392006, органолептические испытания - по ГОСТ 7631-2008, фризико-химические исследования - по ГОСТ 7631-2008 и ГОСТ 7636-85. Содержание токсичных элементов оценивали по ГОСТ 30178-96, количество БГКП - по ГОСТ 31747-12, сульфитредуцирующих клостридий - по ГОСТ 29185-14, S. aureus - по ГОСТ 31746-12, КМАФАнМ - по ГОСТ 10444.15-94. Испытания проводили в трехкратной повторности.

Изучение ассортиментной линейки икры лососевой, реализуемой торговыми предприя-

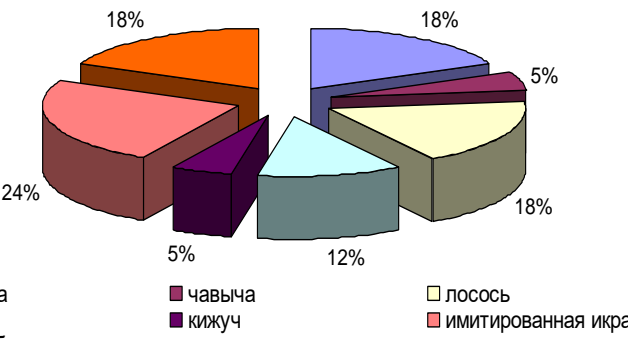

по виду рыбы

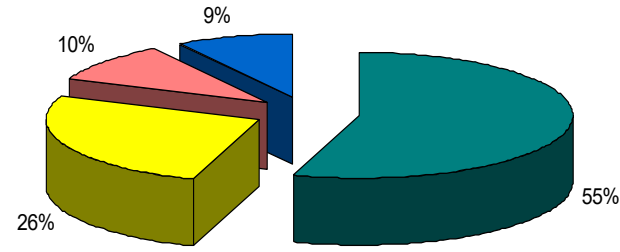

घ90-140 r $\square 140-230 r \quad \square 230-320 r \quad \square 320-500$ r по массе нетто тиями г. Челябинска, показало следующие результаты (рисунок 2): по виду сырья преобладала имитированная лососевая икра, на долю которой приходилось 24 \% от общего количества наименований. В равных долях (по 18 \%) на рынке присутствовала красная икра, полученная при промысле горбуши и лосося. На таком же количестве продукции вид рыбы, из которого получена икра, указан не был. В меньшем объеме присутствовала икра из нерки (12\%), в незначительном (по 5 \%) - икра из чавычи и кижуча.

Лидирующие позиции в ассортименте занимала продукция торговых марок «Хавиар» и «Охотоморье» (по $11 \%$ ) московских поставщиков и «Ромил» (10 \%) - поставщика из Нижегородской области. В одинаковых объемах (по 5 \%) присутствовала икра лососевая ТМ «Дары моря» (г. Москва), «Здоровье» (г. Санкт-Петербург), «Янтарная» (Сахалинская обл.), в меньшем количестве (4 \%) - икра ТМ «Русское море» (Московская обл.).

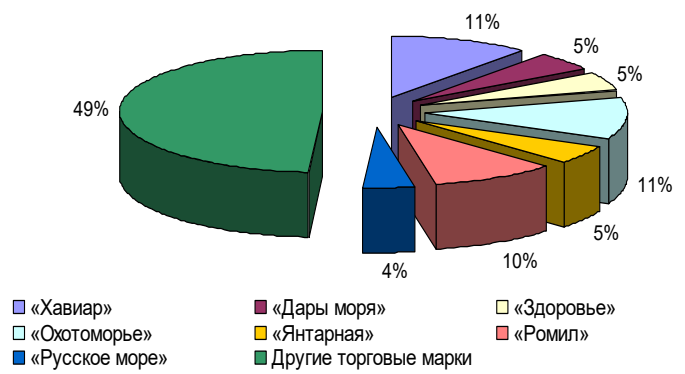

по торговой марке
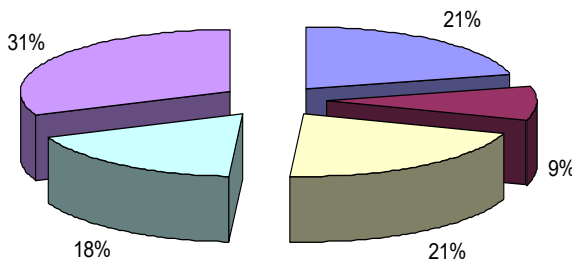

$\begin{array}{ll}\square \text { до } 500 \text { руб. } & \square 500-1000 \text { руб. } \\ \square 3000-4000 \text { руб. } & \square \text { свыше } 4000 \text { руб. }\end{array}$

$\square$ 1000-3000 руб.

по цене за 1 ке продукции

Рисунок 2 - Структура ассортимента икры лососевой по признакам 
К категории «другие торговые марки» была отнесена икра лососевая разных производителей и поставщиков, доля которых на потребительском рынке не превышала $3 \%$.

Каждая вторая банка с икрой была металлической, массой нетто от 90 до 140 г, каждая четвертая - стеклянной, массой нетто от 140 до 230 г. В ценовом диапазоне преобладала икра стоимостью свыше 4000 рублей за 1 кг (31\%). Однако в свободной реализации также находилась икра, рассчитанная на потребителя с низкими и средними доходами.

На этапе изучения качества отобранных проб красной икры особенное внимание уделялось дефектам металлической тары, а именно: деформации корпуса, донышек и крышек, наличию ржавых пятен, целостности продольного и закаточного швов и другое. На всех упаковочных единицах исследуемых образцов икры дефектов обнаружено не было.

Маркировка на дно банок была нанесена разными способами, а именно литографическим или рельефным. Установлено, что на таре икры лососевой «Камчатская рыба» отсутствовал номер смены, в которую была произведена продукция, у образца «Путина» - ассортиментный знак (слово «икра»), номер завода и номер смены, что является нарушением требований ГОСТ 18173-2004. Единственной продукцией, соответствующей требованиям ГОСТ 18173-2004 и ТР ТС 022/2011, являлась икра лососевая «Русская смаковка», которая имела весь перечень условных обозначений.
Надписи на бумажных этикетках у всех проб икры были нанесены литографическим способом, текст читался легко, буквы не были размыты. Выявлено, что знак Евразийского соответствия отсутствовал у всех исследуемых наименований икры лососевой. Товарный знак имелся лишь у имитированной икры «Русское чудо». У продукции «Русская смаковка» не был указан вид рыбы, из которой получили эту икру. В имитированной икре «Русское чудо» по данным маркировки отсутствовали белок и витамины, но содержались жиры и углеводы. Определено наличие информации о подтверждении соответствия у всех испытуемых наименований икры. Пиктограмма петля Мебиуса и знак принадлежности упаковки к материалам, разрешенным для контакта с пищевой продукцией, отсутствовали у икры «Русская смаковка». Таким образом, маркировка всех проб икры не соответствовала в полном объеме требованиям нормативных документов: ГОСТ 18173-2004, TP TC 022/2011, TP ЕАЭС 040/2016.

Результаты экспертизы органолептических показателей изложены в таблице 1. Икра лососевая «Путина» была произведена по ТУ 9264-190-4720930-2009 из мороженого сырья, имитированная икра «Русское чудо» по ТУ 10.20.25-001-4796013-2010, поэтому сопоставление их качества с требованиями ГОСТ 18173-2004 проводилось только в целях выявления лучшего образца из товарованалогов.

Таблица 1 - Результаты органолептических исследований икры лососевой

\begin{tabular}{|c|c|c|c|c|c|}
\hline \multirow{2}{*}{$\begin{array}{l}\text { Показа- } \\
\text { тель }\end{array}$} & \multirow{2}{*}{$\begin{array}{c}\text { Норма для икры перво- } \\
\text { го сорта } \\
\text { (ГОСТ 18173-2004) }\end{array}$} & \multicolumn{4}{|c|}{ Результаты испытаний икры } \\
\hline & & $\begin{array}{c}\text { «Камчатская } \\
\text { рыба» }\end{array}$ & «Путина» & $\begin{array}{c}\text { «Русская } \\
\text { смаковка» }\end{array}$ & $\begin{array}{c}\text { «Русское } \\
\text { чудо» }\end{array}$ \\
\hline 1 & 2 & 3 & 4 & 5 & 6 \\
\hline $\begin{array}{c}\text { Внешний } \\
\text { вид }\end{array}$ & $\begin{array}{l}\text { Икра одного вида } \\
\text { рыбы, однородного } \\
\text { цвета. Икринки чи- } \\
\text { стые, целые, без } \\
\text { пленки и сгустков } \\
\text { крови. Могут быть: } \\
\text { незначительное коли- } \\
\text { чество оболочек икри- } \\
\text { нок - лопанца; неод- } \\
\text { нородность цвета для } \\
\text { икры кижуча и нерки }\end{array}$ & $\begin{array}{l}\text { Икра одного } \\
\text { вида } \quad \text { рыбы } \\
\text { (горбуши), од- } \\
\text { нородного цве- } \\
\text { та. Икринки } \\
\text { чистые, целые, } \\
\text { без пленки и } \\
\text { сгустков крови }\end{array}$ & $\begin{array}{l}\text { Икра одного вида } \\
\text { рыбы (лосося), } \\
\text { неоднородного } \\
\text { цвета, целостность } \\
\text { икринок нарушена, } \\
\text { имеются пленка и } \\
\text { незначительное } \\
\text { количество оболо- } \\
\text { чек икринок- } \\
\text { лопанца }\end{array}$ & $\begin{array}{l}\text {, Икра неодно- } \\
\text { родного цвета, } \\
\text { нарушена це- } \\
\text {, лостность икри- } \\
\text { иок, значитель- } \\
\text { ное количество } \\
\text { - оболочек икри- } \\
\text { - нок-лопанца }\end{array}$ & $\begin{array}{l}\text {, Икра однород- } \\
\text { ного цвета, } \\
\text { - икринки чистые, } \\
\text { - целые, } \\
\text { пленки и сгуст- } \\
\text { - ков крови }\end{array}$ \\
\hline $\begin{array}{l}\text { Консистен- } \\
\text { ция и состо- } \\
\text { яние }\end{array}$ & $\begin{array}{l}\text { Икринки упругие, со } \\
\text { слегка влажной или } \\
\text { сухой поверхностью, } \\
\text { разбористые - отде- } \\
\text { ляются одна от другой }\end{array}$ & $\mid \begin{array}{lr}\text { Икринки } & \text { упру- } \\
\text { гие, со слегка } \\
\text { влажной } \\
\text { верхностью, по- } \\
\text { разбористые }\end{array}$ & $\begin{array}{l}\text { Незначительно } \\
\text { нарушена упру- } \\
\text { гость икринок }\end{array}$ & $\begin{array}{l}\text { Значительно } \\
\text { нарушена кон- } \\
\text { систенция, } \\
\text { состояние } \\
\text { напоминает } \\
\text { бульон с лоп- } \\
\text { нувшими икрин- } \\
\text { ками }\end{array}$ & $\begin{array}{l}\text { Икринки упругие } \\
\text { со слегка влаж- } \\
\text { ной поверхно- } \\
\text { стью, разбори- } \\
\text { стые }\end{array}$ \\
\hline
\end{tabular}


Продолжение таблицы 1

\begin{tabular}{|c|c|c|c|c|c|}
\hline 1 & 2 & 3 & 4 & 5 & 6 \\
\hline Запах & $\begin{array}{lr}\text { Свойственный } & \text { икре } \\
\text { данного } & \text { вида рыбы, } \\
\text { без } & \text { постороннего } \\
\text { запаха } & \end{array}$ & $\begin{array}{l}\text { Свойственный } \\
\text { икре данного } \\
\text { вида рыбы, без } \\
\text { постороннего } \\
\text { запаха }\end{array}$ & $\begin{array}{l}\text { Свойственный икре } \\
\text { данного вида ры- } \\
\text { бы, с горьковатым } \\
\text { запахом }\end{array}$ & $\begin{array}{l}\text { Свойственный } \\
\text { данному виду } \\
\text { продукции, } \\
\text { слабовыражен- } \\
\text { ный }\end{array}$ & $\begin{array}{l}\text { Несвойствен- } \\
\text { ный данному } \\
\text { виду продукции, } \\
\text { с сильно выра- } \\
\text { женным запа- } \\
\text { хом ароматиза- } \\
\text { тора }\end{array}$ \\
\hline Вкус & $\begin{array}{l}\text { Свойственный икре } \\
\text { данного вида рыбы, } \\
\text { без постороннего } \\
\text { привкуса. Могут быть: } \\
\text { привкус горечи для } \\
\text { икры кижуча и нерки, } \\
\text { слабые привкусы } \\
\text { горечи и остроты }\end{array}$ & $\begin{array}{l}\text { Свойственный } \\
\text { икре данного } \\
\text { вида рыбы, без } \\
\text { постороннего } \\
\text { привкуса }\end{array}$ & $\begin{array}{l}\text { Свойственный икре } \\
\text { данного вида рыбы } \\
\text { с выраженными } \\
\text { привкусами - соло- } \\
\text { новатым и горечи }\end{array}$ & $\begin{array}{l}\text { Свойственный } \\
\text { данному виду } \\
\text { продукции } \\
\text { выраженными } \\
\text { привкусами } \\
\text { солоноватым и } \\
\text { горечи }\end{array}$ & $\begin{array}{l}\text { Свойственный } \\
\text { данному виду } \\
\text { продукции, без } \\
\text { постороннего } \\
\text { привкуса }\end{array}$ \\
\hline
\end{tabular}

Определено, что по органолептическим показателям требованиям ГОСТ 18173-2004, предъявляемым к продукции первого сорта, соответствовала икра горбуши «Камчатская рыба». Остальные образцы икры не укладывались в нормы действующего стандарта по тем или иным органолептическим характеристикам. Так, икра «Русская смаковка» по консистенции напоминала бульон с лопнувшими икринками, имела выраженные привкусы горечи и соли. Имитированная икра лососевая «Рус- ское чудо» отличалась несвойственным, сильно выраженным запахом ароматизатора. Продукция «Путина» при опробовании имела выраженный солоноватый привкус и горечь, проявляющуюся не только во вкусе, но и в запахе.

Известно, что при избытке поваренной соли трудно достичь требуемого вкуса, в том числе из-за появляющейся горечи $[9,10]$. В этой связи были изучены фризико-химические показатели исследуемых образцов икры (таблица 2).

Таблица 2 - Результаты фризико-химических исследований икры лососевой

\begin{tabular}{|c|c|c|c|c|c|}
\hline \multirow[b]{2}{*}{ Показатель } & \multirow{2}{*}{$\begin{array}{c}\text { Норма } \\
\text { (ГОСТ 18173-2004, } \\
\text { ГОСТ 8.579-2002) }\end{array}$} & \multicolumn{4}{|c|}{ Результаты испытаний икры } \\
\hline & & $\begin{array}{c}\text { «Камчатская } \\
\text { рыба» }\end{array}$ & «Путина» & $\begin{array}{c}\text { «Русская } \\
\text { смаковка» }\end{array}$ & $\begin{array}{l}\text { «Русское } \\
\text { чудо» }\end{array}$ \\
\hline Герметичность банок & герметичны & \multicolumn{4}{|c|}{ герметичны } \\
\hline $\begin{array}{l}\text { Масса нетто, } \\
\text { заявленная в } \\
\text { маркировке, г }\end{array}$ & \multirow{2}{*}{$\begin{array}{l}\text { при массе нетто до } \\
100 \text { г - допускается } \\
\text { отрицательное от- } \\
\text { клонение } 4,5 \text { г, } \\
\text { при массе нетто 100- } \\
500 \text { г - допускается } \\
\text { отрицательное от- } \\
\text { клонение 4,5 \% }\end{array}$} & 140 & 95 & 130 & 120 \\
\hline $\begin{array}{l}\text { Масса нетто } \\
\text { фрактическая, г }\end{array}$ & & $140,0 \pm 1,9$ & $95,0 \pm 1,7$ & $130,0 \pm 1,1$ & $120,0 \pm 1,4$ \\
\hline $\begin{array}{l}\text { Массовая доля пова- } \\
\text { ренной соли, \% }\end{array}$ & $\begin{array}{l}\text { 4-6 (для икры перво- } \\
\text { го сорта) }\end{array}$ & $5,21 \pm 0,05$ & $7,10 \pm 0,03$ & $6,70 \pm 0,04$ & $5,42 \pm 0,02$ \\
\hline $\begin{array}{l}\text { Наличие посторонних } \\
\text { примесей }\end{array}$ & не допускается & \multicolumn{4}{|c|}{ не обнаружено } \\
\hline Содержание белка, \% & \multirow{3}{*}{$\begin{array}{c}\text { не регламентирует- } \\
\text { ся }\end{array}$} & $32,6 \pm 0,2$ & $31,9 \pm 0,1$ & $32,2 \pm 0,2$ & - \\
\hline Содержание жира, \% & & $13,72 \pm 0,06$ & $11,21 \pm 0,05$ & $12,36 \pm 0,06$ & $3,42 \pm 0,03$ \\
\hline Содержание влаги, \% & & $48,9 \pm 0,8$ & $52,1 \pm 0,7$ & $50,7 \pm 0,6$ & $48,7 \pm 0,7$ \\
\hline $\begin{array}{l}\text { Содержание } \\
\text { бензоата натрия, \% }\end{array}$ & не более 0,1 & $0,081 \pm 0,002$ & $0,089 \pm 0,002$ & $0,073 \pm 0,003$ & - \\
\hline $\begin{array}{l}\text { Содержание } \\
\text { сорбиновой } \\
\text { кислоты, \% }\end{array}$ & не более 0,1 & $0,073 \pm 0,002$ & $0,091 \pm 0,001$ & $0,075 \pm 0,002$ & - \\
\hline
\end{tabular}


Установлена герметичность металлической тары всех наименований икры лососевой. Посторонние примеси не были обнаружены ни в одной из отобранных проб. Выявлено, что масса продукта, заявленная на этикетке каждого образца, соответствовала нормам ГОСТ 8.579-2002. В икре наименований «Путина» и «Русская смаковка» было обнаружено превышение верхнего предела содержания поваренной соли на 18,3 и $11,7 \%$ соответственно, что согласовалось с результатами органолептических испытаний.

Содержание белка во всех образцах зерновой икры находилось в пределах 32 \%, содержание консервантов - не превышало норм ГОСТ 18173-2004. У имитированной икры «Русское чудо» эти компоненты не опре- деляли за неимением в составе продукта.

Большим количеством жира отличалась красная икра «Камчатская рыба» $(13,72 \pm 0,06 \%)$, меньшим - имитированная икра «Русское чудо» $(3,42 \pm 0,03 \%)$. Относительно высокое содержание влаги $(52,1 \pm 0,7 \%)$ было обнаружено у икры лососевой «Путина», произведенной из мороженого сырья.

Микробиологическая составляющая в любом виде испытаний пищевых продуктов является важной частью протокола исследований. В этой связи была изучена микробиологическая безопасность отобранных проб икры. Результаты заключительной стадии испытаний представлены в таблице 3.

Таблица 3 - Результаты исследований показателей безопасности икры лососевой

\begin{tabular}{|c|c|c|c|c|c|}
\hline \multirow[b]{2}{*}{ Показатель } & \multirow{2}{*}{$\begin{array}{c}\text { Норма } \\
\text { (ТР ЕАЭС 040/2016, } \\
\text { ТР ТС 021/2011, } \\
\text { СанПиН 2.3.2.1078-01) }\end{array}$} & \multicolumn{4}{|c|}{ Результаты испытаний икры } \\
\hline & & $\begin{array}{c}\text { «Камчатская } \\
\text { рыба» }\end{array}$ & «Путина» & $\begin{array}{c}\text { «Русская } \\
\text { смаковка» }\end{array}$ & $\begin{array}{l}\text { «Русское } \\
\text { чудо» }\end{array}$ \\
\hline \multicolumn{6}{|c|}{ Микробиологические показатели: } \\
\hline $\begin{array}{l}\text { КМАФАнМ, } \\
\text { КОЕ/г }\end{array}$ & $\begin{array}{c}\text { не более } 5,0 \times 10^{3}, \\
\text { не более } 1,0 \times 10^{4} \\
\text { (для аналога икры) } \\
\end{array}$ & $3,2 \times 10^{2}$ & $2,5 \times 10^{2}$ & $4,1 \times 10^{2}$ & $2,8 \times 10^{3}$ \\
\hline $\begin{array}{l}\text { БГКП (колифор- } \\
\text { мы) в 1,0 г икры } \\
\text { (в 0,1 г аналога } \\
\text { икры) }\end{array}$ & \multirow{3}{*}{ не допускаются } & \multicolumn{4}{|c|}{ не обнаружены } \\
\hline $\begin{array}{l}\text { Сульфитреду- } \\
\text { цирующие кло- } \\
\text { стридии в } 1,0 \text { г } \\
\text { икры (в 0,1 г } \\
\text { аналога икры) }\end{array}$ & & \multicolumn{4}{|c|}{ не обнаружены } \\
\hline $\begin{array}{llll}\text { S. aureus в } 1 \text { г } \\
\text { продукта }\end{array}$ & & \multicolumn{4}{|c|}{ не обнаружены } \\
\hline \multicolumn{6}{|c|}{ Токсичные элементы, мг/кг: } \\
\hline Свинец & не более 1,0 & $0,041 \pm 0,003$ & $0,034 \pm 0,003$ & $0,037 \pm 0,004$ & $0,028 \pm 0,002$ \\
\hline Кадмий & не более 1,0 & $0,010 \pm 0,002$ & $0,010 \pm 0,002$ & $0,011 \pm 0,002$ & $0,090 \pm 0,003$ \\
\hline
\end{tabular}

По итогам исследований санитарногигиенических показателей образцов икры лососевой не выявлено отклонений от требований действующей нормативной документации: TP ЕАЭС 040/2016, TP TC 021/2011, СанПиН 2.3.2.1078-01. Санитарнопоказательные бактерии, патогенные микроорганизмы и сульфитредуцирующие клостридии не были выявлены в определенной массе продукции. Количество мезофильной микрофрлоры находилось в пределах нормы.

Относительно высокое содержание такого токсичного элемента, как кадмий, было установлено в имитированной икре «Русское чудо», однако это количество не превысило норм регламентированных требований. Концентрации свинца имели некоторые колебания от пробы к пробе, но соответствовали требованиям технических регламентов и санитарных правил и норм.

Таким образом, при изучении структуры ассортимента икры лососевой, реализуемой на потребительском рынке г. Челябинска, установлено, что по количеству наименований преобладала имитированная икра, из зернистой - икра горбуши и лосося в металлической таре, массой нетто от 90 до 140 г, рассчитанная на покупателя с разным уровнем достатка, от московских поставщиков.

Маркировка исследуемой икры наимено- 


\section{СТРУКТУРА АССОРТИМЕНТА И КАЧЕСТВО ИКРЫ ЛОСОСЕВОЙ, РЕАЛИЗУЕМОЙ НА ПОТРЕБИТЕЛЬСКОМ РЫНКЕ Г. ЧЕЛЯБИНСКА}

ваний «Камчатская рыба», «Путина», «Русская смаковка», «Русское чудо» не соответствовала требованиям нормативных документов: ГОСТ 18173-2004, ТР ТС 022/2011, ТР ЕАЭС 040/2016. По органолептическим и физико-химическим показателям требованиям ГОСТ 18173-2004, предъявляемым к продукции первого сорта, соответствовала икра горбуши «Камчатская рыба». Микробиологическая и токсикологическая безопасность отобранных проб икры лососевой соответствовала нормам ТР ТС 021/2011, ТР ЕАЭС 040/2016, СанПиН 2.3.2.1078-01.

Исследования выполнены при поддержке Правительства РФ (Постановление № 211 от 16.03.2013 г.), соглашение № 02.A03.21.0011.

\section{СПИСОК ЛИТЕРАТУРЫ}

1. Лаптева, Е. П. Анализ и оценка рисков при производстве икры лососевой зернистой баночной / Е.П. Лаптева // Научные труды дальневосточного государственного технического рыбохозяйственного университета. - 2016. - № 2. C. $77-81$.

2. Рубцова, Т. Е. Пищевая ценность икры лососевых / Т. Е. Рубцова. - Санкт-Петербург: Рыбпром № 1, 2009. - 308 с.

3. Ахмерова, Е. А. Пищевая ценность икры рыб / Е. А. Ахмерова, Л. Р. Копыленко, Т. Е. Рубцова // Вестник биотехнологии и физикохимической биологии им. Ю.А. Овчинникова. 2012. - T. 8, № 4. - C. 12-20.

4. Серегин, И. Г. Совершенствование ветсанэкспертизы икры лососевых рыб / И. Г. Серегин, Д. В. Никитченко, М. И. Михеева // Вестник РУДН. - 2017. - Т. 12, №3. - С. 279-288.

5. Михлай, С. А. Результаты исследований показателей качества и безопасности водных биоресурсов на маршрутах транспортировки, хранения и реализации / С. А. Михлай, Л. Х. Вафинна, Т. Е. Рубцова, Ю. Е. Барышникова // Труды ВНИPO. - 2016. - T. 159. - C. 43-47.

6. Хамзина, А. К. Обоснование технологии икры лососевой из мороженых ястыков / А. К. Хамзина, Л. Р. Копыленко, Л. Д. Курлапова, Л. Х. Вафина // Труды ВНИРО. - 2016. - Т. 159. C. 119-129.

7. Ратов, И. Н. Товароведение рыбных товаров и нерыбных морепродуктов / И. Н. Ратов. -
Москва: Пищепромиздат, 2012. - 104 с.

8. Добренкова, С. В. Причины снижения качества икры зернистой лососевой и возможные пути их решения / С. В. Добренкова, Л. С. Абрамова, Л. Х. Вафина // Рыбное хозяйство. - 2017. № 3. - C. 104-108.

9. Балыкова, Л. И. Исследование процессов замораживания соленой пробойной икры минтая без консервантов / Л. И. Балыкова, К. В. Алтухов // Научный журнал Кубанского государственного аграрного университета. - 2007. - № 9 (33). C. 78-91.

10. Inanli, A. G. The chemical and sensorial changes in rainbow trout caviar salted in different ratios during storage / A. G. Inanli, Ö. E. Coban, M. Dartay // Fisheries Science. - 2010. - V. 76. P. 879-883.

Наумова Наталья Леонидовна, д.т.н., профрессор кафредры пищевых и биотехнологий ФГАОУ ВО «Южно-Уральский государственный университет (национальный исследовательский университет)», 454080, 2. Челябинск, Проспект Ленина, 76, e-mail: n.naumova@inbox.ru

Макаева Ольга Александровна, cmyдент бакалавриата кафедры пищевых $u$ биотехнологий ФГАОУ ВО «ЮжноУральский государственный университет (национальный исследовательский универcumem)», 454080, г. Челябинск, Проспект Ленина, 76

Бурмистров Евгений Александрович, к.с.-х.н., старший преподаватель кафедры ветеринарно-санитарной экспертизы и товароведения потребительских товаров ФГБОУ ВО «Южно-Уральский государственный аграрный университет», 457100, Челябинская область, г. Троицк, ул. Гагарина, 13, e-mail: olgatzareva@rambler.ru

Бурмистрова Ольга Михайловна, к.с.-х.н., доцент кафредры ветеринарносанитарной экспертизы и товароведения потребительских товаров ФГБОУ ВО «Южно-Уральский государственный агра-рный университет», 457100, Челябинская область, г. Троицк, ул. Гагарина, 13, е-таil: olgatzareva@rambler.ru 